\title{
The Health Life Quality Portrait of Kaili Da'a Women Couples Violence for the Victims of Tsunami, Earthquake, and Liquefaction through Family Economic Empowerment in Central Sulawesi Indonesia
}

\author{
${ }^{1 *}$ Sitti Rahmawati, ${ }^{2}$ Dilaver Tengilimoglu, ${ }^{3}$ Sonia Diaz Monsalve , ${ }^{4}$ Bohari, ${ }^{5}$ Andi Herman \\ Jaya, ${ }^{6}$ Santi Yunus, ${ }^{7}$ Nurulhuda Rahman
}

\begin{abstract}
${ }^{1}$ Department of Economics and Business Development Studies of Health Economics Specialization, Tadulako University, Central Sulawesi, Indonesia.

${ }^{2}$ Department of Institute Graduate School of Social Sciences Atilim University Ankara Turkey

${ }^{3}$ Department Global Health University of Freiburg Germany.

${ }^{4}$ Department of Nutrition, Faculty of Public Health, Tadulako University, Central Sulawesi, Indonesia.

${ }^{5}$ Department of Economics and Business, Tadulako University, Central Sulawesi, Indonesia.

${ }^{6}$ Department of Economics and Business, Tadulako University, Central Sulawesi,Indonesia

${ }^{7}$ Department of Statistics, Faculty of Mathematics and Natural Science, Tadulako University, Central Sulawesi, Indonesia
\end{abstract}

Corresponding Author Email: siti131962@gmail.com

Mobile +62 081242551424

\begin{abstract}
Background: The tsunami and earthquake occurred in 1927 and 2018 made life quality of Da'a Tribe women in refugee camps was affected by violence. It affects on women reproductive health in various aspects of life as high maternal mortality rate of 450 per 100 thousand live births and half of women victims of natural disasters have reproductive health problems such as anemia and malnutrition during pregnancy. The study objective is to explore the health quality of women related to the couple violence during the humanitarian crisis at refugees' camps.

Method: The population was 798 cases of violence. The 90 samples were selected by simple random sampling and calculated by Slovin method. Data analysis was done by descriptive qualitative and cross tabulation. The research location was Palu City.

Results: The research findings showed that health quality of Da'a Tribe women after the couple violence is influenced by three factors, namely economic by $40 \%$, psychological by $7 \%$, violence during pregnancy $59.3 \%$.

Conclusion: Social life and women violence handling can be done by symbolizing the threat of criminal law for male perpetrators in accordance with applicable laws in Indonesia and improving the life quality of population, especially women in education and skills through empowering the family economy and increasing gender equality justice.
\end{abstract}

Keywords: life quality, women's health, family empowerment 


\section{BACKGROUND}

The Sustainable Development Goals (2015-2030) produced 17 SDGs objectives, including three areas related to women's health quality, it includes 1) Achieving good health and prosperity, 2) Achieving high quality education, and achieving gender equality [1] [2]. One most important unachieved issue is the international commitment through the direction of Sustainable Development Goals (SDG's) movement, where gender equality in social life conflict and life quality of women are considered low in community. There were much physical violence against women and trafficking (United Human Rights, 2014, CEDAV, 2017) [1], [3]. Human Rights Committee for elimination of discrimination against women from WHO (2017) stated that violence is the use of physical force and power, threats or actions against oneself, individuals or groups of people (society) to create woman's body bruises or trauma, death, economic, psychological or physical deprivation to causes injury or death to others and law violence. The concerned violence victims are women. They really need protection in economic development activities. The couple violence becomes the devastating for public health problem in United States. The rate of violence is 50-60 percent. This needs concern to prevent victimization aimed at treatment of offenders, in terms of demographic aspects that will affect treatment completion which is tailored to individual care needs [4]. Adolescent violence is an urgent international problem, highest prevalence found in Europe and North America where psychological / emotional violence is most frequent and sexual violence is rare. Four risk factors of crime are 1) Peer influence on violence, 2). drug abuse, 3). psychological development, 4). Changes in attitude [5].

Gender violence and natural disasters can be learned from New Orleans, Haiti and Christchurch [6]. Women so vulnerable to violence and deaths from disasters compared to men. The economic and social status of women who are not equal to men before the disaster determines their vulnerability to violence during the crisis. If gender violence is not addressed the special needs of women are not addressed in disaster preparedness, disaster recovery plans and humanitarian assistance, vulnerability of women and girls increases, planning for future disaster decision making is sensitive to gender. Natural disasters can increase the level of violence both short-term and long-term experiencing mental distress, stress disorders, depression, anxiety disorders [5]. The results of this study reveal that being exposed to natural 
disasters such as tsunami, storms, earthquakes, and floods can increase violence against women and girls for example, rape and sexual abuse [7]-[9], PTSD children [9], child abuse [10], [11] and cause traumatic brain injury [12]. After the tsunami disaster women and children can be separated from their families and they face a greater risk of experiencing personal violence and suicide after the disaster [3]. In emergency situations such as this, attention is paid to single women and girls [13], and provides appropriate health services, counseling and legal support for victims of such violence [3]. Nevertheless the results of some recent studies suggest that self-directed violence and interpersonal violence can increase after natural disasters, such as earthquakes, floods, tropical storms and so on [14]-[17]. Therefore, in this article focus on relationship between violence and natural disasters of tsunami, earthquakes and liquefaction by looking at epidemiology of health of women who experience violence from the couple [16].

Social unrest, post-conflict conflict victims of tsunami and earthquake and liquefaction accommodate many problems that require serious handling, but have not been handled properly. It seems that socio-economic vulnerability experienced by victims of domestic violence that become conflict victims of tsunami and an earthquake on September 28, 2018, a number of people died, and some lived in refugee camps. National Disaster Management Agency (BNPB) Report On October 10, 2018 that victims of tsunami and earthquake died, liquefaction reached 2,045, found in Palu at 1,636 and followed by Sigi and then Parigi [18]. Meanwhile, 82,775 displaced victims and 8,731 displaced people were in Palu City, and some households lost their homes, trauma, depression and property loss which caused economic poverty but trauma traumatized widows (76\%) and status non widows (26\%) live in refugee camps affected by tsunami and earthquake, and liquefaction. Domestic violence, after the earthquake and liquefaction conflict occurred on September 28, 2018, had a negative effect on lives of people of Central Sulawesi. unrecorded data and thousands of people who died.

The natural disasters Tsunami, Earthquake makes many women become widow and responsible for burden of family life [19], [20]. Women who are separated from extended families become "alone" while children become orphans and depend on adult women for their lives. This makes women bear a double burden. A more serious consequence is that some women are forced into world of prostitution, seen from. the life quality of individuals there is a patriarchal construction and gender subordination in context of conflict places women highly vulnerable to sexual harassment, intimidation, mistreatment, and even rape. Sexual harassment 
is seen from physical aspect that life quality of a widow is low. One hand there is an increase in morbidity and mortality due to infectious diseases, one of which is rape and sexual abuse increased mitigation in aftermath of earthquake and tsunami disaster found a tent at evacuation site of victims of sexual harassment and rape who are not husband or wife [21], [22]. Most mitigation after natural disasters, earthquake, and tsunami causes poor sanitation; people live in emergency tents in groups in refugee camps [20], [23]. Tsunami and earthquake natural disasters have been proven to be able to change and affect human life from various aspects, especially social, economic and health. In last two years, after the tsunami disaster has claimed thousands of lives and affected the lives of population in Central Sulawesi due to lack of resources, infrastructure and weak preparedness system in dealing with natural disaster mitigation, and how to deal with gender perspective violence in aftermath of tsunami and earthquake in Sulawesi. The middle.

\section{History of Earthquakes, Tsunami and Liquefaction in Central Sulawesi}

National Agency for Disaster Management in Central Sulawesi found 11 earthquake events occurred. First was December 1927 with magnitude of 6, 5 in Watusampu Donggala District with 14 fatalities and 50 people injured. Second was $30^{\text {th }}$ June 1930 at West coast of Donggala District with tsunami potential. Third was $14^{\text {th }}$ August 1938 with 6 magnitudes at Balesang Sub-district. Forth was in 1994 at Donggala District. Fifth was $1^{\text {st }}$ January 1996 with magnitude of 7.4 in Makassar Strait. Sixth was in 1996 at Tonggolobibi and Bankir in Donggala District. Seventh was $11^{\text {th }}$ October 1998 in Donggala District with magnitude of 5.5. Eight was $24^{\text {th }}$ January 2005 at Central Sulawesi with magnitude of 6.2 from epicenter $16 \mathrm{~km}$ southeast of Palu City. Ninth was $7^{\text {th }}$ November 2008 with magnitude of 7.7 in Sulawesi Sea to shake Buol District. Tenth was $18^{\text {th }}$ August 2012 with magnitude of 6.2 at 8 fatalities. Eleventh was $28^{\text {th }}$ September 2018, with magnitude of 6,8 the earthquake, tsunami and liquefaction produce 2045 fatalities and 82775 people displaced. 2018 is the most devastating earthquake phenomenon of many earthquake data in Central Sulawesi with potential to cause tsunami and liquefaction [18].

The study objective is to explore the health quality of women related to the couple violence during the humanitarian crisis at refugees camps. 


\section{LITERATURE AND REFERENCE}

The human life quality has high correlation with lives and individuals development in education and health. Higher women's health can improve the life quality for women. Lower violence means the life quality of women is still relatively high [3], [14]. Theories of Violence in Social Science Perspectives showed the violence in sociology, psychology, anthropology, and political economy. The analysis and synthesis of these fields relate to violence [24]. Conceptual framework of social behavior from interactive human correlations with social environments relates with gender perspective. The concept of domestic violence relates with woman that produce physical, sexual, psychological and physical misery and neglect of household, including threats to coercive acts and deprivation that violate the household law. Most victims of domestic violence are women (wives) and the perpetrators are husbands. Violence based on gender can be divided into three parts namely sexual assault, economic violence and psychological violence, Various steps are taken to create equality between men and women, among others by developing family economic entrepreneurship to balance the role between men and women in family to jointly develop the family economy. Patriarchal culture put women who in a weak bargaining position. The women effort to get the reproductive rights in decision-making is not heeded in family. The marginalization, discrimination and exploitation become the severity problem faced by world population, therefore gender mainstreaming in poverty reduction becomes a very important part in economic development. Asymmetric populations of gender show more men than women are arrested and more women seek protection in courts and police due to violence from victims of natural disasters [5].

Couple violence occurs at a very high level. The recent survey in America showed more than 7 million women and 5.5 million men get physical violence, stalking, or being raped by the couple each year. Physical health symptoms of the couple include bruising, injury, soft tissue, sprains, broken bones, brain injury, traumatic, disability and death, and increased drug use disorders of the couple victims [25]. The document of Sustainable Development Goals on 25 September 2015 at United Nations Headquarters (UN) was signed by 193 countries leader to make global development agreement. Achievement of Sustainable Development Goals (SDG's) gave birth to 17 Goals of SDGs, including the elimination of poverty, ending hunger, achieving good primary health care programs and welfare, handling maternal and child health in earthquake and tsunami disasters, and achieving quality education to achieve gender 
equality, eliminating all forms of violence against women in public and private sphere, including trafficking and sexual exploitation and other forms of exploitation [2]. Traffickers around the world are women, including girls-elderly aged around 30 percent in 2000-2012 periods. Around 49 percent the trafficking victims are women. A total of 69 percent of trafficking for sexual exploitation are women, while 75 percent of labor exploitation victims are men. Victims in other forms of exploitation are girls, theft and child trafficking, with women at 52 percent and 38 percent men and 10 percent are victims of unknown gender [14]. The patriarchal construction and gender subordination (especially in the context of conflict) place the quality of life of women very vulnerable to sexual harassment, intimidation, persecution, and even rape. Another sexual harassment that is often experienced is seeing a widow physically survive in refugee camps [26]. explained that domestic violence is one of the most expensive and severe health problems facing society today which affects all cultural backgrounds, sexual orientation, age, ethnicity, education level and lower economic class. Research in the United States nationally more than 9000 women, about one in three women (36\%) experienced rape, physical violence with their spouse during married life. Prevention of violence can be done by intervention studies comparing the level of violence with student respondents with green dot by standards $(\mathrm{n}=2768)$, with a two university study without an observational program $(n=4258)$ on campus Green dot by standard [27]. The challenge of domestic violence that is often associated with interpersonal trauma can be done with therapy for 16 weeks to carry out a model of economic recovery of family surgery [28]. Social conflicts of female violence victims were 213 women disclosed sexual violence and 56 percent reported sexual cases to law enforcers to be given the threat of criminal law [21]. In general, women included in the marginalized group of oppressed are at greater risk of experiencing domestic violence. The phenomenon of community life towards violence by poor women after the disaster and tsunami has shown an increase in the number in the last two years. Lloyd explains to women to improve the quality of life of women by empowering the family economy to increase the income of poor families [18], [24], [25].

WHO stated that violence is the use of physical force and power, threats or actions against oneself, individuals or groups of people (society) to produce woman's body bruises or trauma, death, economic, psychological or physical deprivation [14]. Husband violence against wife is unlawful behavior that cause injury or death to other people and cause physical damage 
to others. In these conditions, construction of patriarchy and gender subordination (especially in context of conflict) makes women very vulnerable to sexual harassment, intimidation, persecution, and even rape. Another sexual harassment is often experienced widows in refugee camps. The domestic violence is one most expensive and severe health problems to affects all cultural backgrounds, sexual orientation, age, ethnicity, education level and lower economic class [26]. United States has more than 9000 women, about one in three women (36\%) experienced rape, physical violence by their spouse during married life. Prevention of violence can be done by intervention studies to compare the level of violence of student respondents at Green dot campus $(\mathrm{n}=2768)$, with a two-university study without an observational program ( $\mathrm{n}$ = 4258). The Green dot campus become standard [27]. The challenge of domestic violence with interpersonal trauma can be handled by therapy for 16 weeks to carry out a model of economic recovery of family surgery [28]. The female violence victims were 213 women disclosed sexual violence and 56 percent reported sexual cases to law enforcers to get criminal law [21]. Women in the marginalized group have greater risk to get domestic violence. The phenomenon shows the violence by poor women after the disaster and tsunami has increased in last two years. Lloyd explained that women quality life improvement can be done by empowering the family economy to increase the income of poor families [18], [24], [25].

Central Sulawesi Province in 2018 showed 450 cases of sexual violence and rape and after the tsunami and earthquake increased to 798 cases in 2019. Higher female violence become a global problem of society and generally violates human rights that harmful and has an effect on women's reproductive health and family welfare [2], [29]. There are various terms such as "Violence against women," gender based violence, "domestic violence" whose victims are women, while for children known as working children or street children at urban zones [14] [30]. The gender analysis and social transformation put the violence in household occur due to socio-cultural factors where the wife is perceived as a second person and can be applied to anything by her the couple. In 2004, Law on Elimination of Domestic Violence was enacted, so acts of domestic violence were not only a matter of husband and wife but had become a public affair, and beating a wife was a manifestation of superior nature of men against women [20], [31]. Female violence causes death, including women who experience physical violence around (30\%) tend to have one child who died, OR 1 (, 30\%), $\mathrm{Cl}$ (1.05-1.60\%), more children died, OR (45.95\% CL (1.06-2.00). The children violence was occurred at more than five years old. 
Laura described gender-based sexuality violence related to lower social status to cause the couple violence [25].

\section{RESEARCH METHOD}

This research design uses positive paradigm based on reality and using descriptive qualitative methods. The data is collected by in-depth interviews, Focus Group Discussion and observation. The data sources are primary and secondary. The key informants are selected by purposive sampling technique. Data collection techniques are observation, interview guides, study documents and triangulation.

\section{Population and Sample}

The population was 798 cases of violence in Sigi District and Palu City (PASIGALA), Central Sulawesi, Indonesia. These regions show very high rate of domestic violence. Data sources were Religion Office and Office of Women's Empowerment in Central Sulawesi.

\section{Sample}

The research sample was taken by simple random sampling for women refugee of tsunami, earthquake and liquefaction. The samples are 90 respondents at Sigi District and Palu City, with consideration that these two districts are very sensitive as research samples, these areas show very high level of household violence. The calculation is follows:

$\mathrm{n}=\mathrm{N}$

$1+\mathrm{Ne}^{2}$

$\mathrm{n}=$ number of Samples

$\mathrm{N}=$ Total population 798 cases of violence

$\mathrm{e}^{2}=$ Error tolerance

$$
\begin{aligned}
& \mathrm{n}=\mathbf{7 9 8}= \\
& 1+798(0.1) 2
\end{aligned}
$$

$=8.98$, rounded to 90 respondents

Total 45 respondents are selected from Palu City and other 45 respondents from Sigi District. Total respondents were 90 respondents. The tolerance is 10 percent, it means the accuracy rate is 90 percent. 


\section{RESULTS}

\section{A. Socio-Economic and Demographic Characteristics Respondents}

These study informants are married women, some are relatively long for 18 years and 10 years but later divorced due to domestic violence cases. There is also young age of marriage for 2-5 years. All informants went out of courtship before marriage, for five years and less than two years of courtship. The time period of dating period cannot be used as a benchmark for couple because they have known each other's personalities. Introducing the courtship period can continue at time of marriage and is proven to behave badly on his wife, causing physical violence to women's reproductive health. Their household life before the earthquake and tsunami did not occur conflict, but after the earthquake and tsunami the social conflict was occurred.

The post-disaster and tsunami produce psychological violence that accompany sexual and physical violence. The informants suffer more than one type of violence. The informant's statement was follows: "Sexual violence was happened, sometimes the husband comes home at midnight and drunk, beaten ... slapped, slapped, slammed, sometimes he pulls his clothes and down ... he say dogs, slats, so many dogs., punch worn on cheek" (informant 18 September 2019). Physical violence of the victims was stated by key informants namely the head of Office of Women's Empowerment who handled cases of victims of female violence (P2TP2A). She said that physical and psychological violence was very sad violence and did not occur once but repeatedly. The husband sometimes is more emotional because there is no work, then drink beer alcohol (Al, 12 April 2019). But there are also victims who experience the frequency of physical violence only twice during the marriage but even for economic violence they receive it every day which is insufficient in meeting the needs of their household lives. The place of violence is Palu City. General description explains the of age characteristics of respondents who were violated by domestic violence The average age of respondents who are above 40 years (39\%), and 31-40 years old (23\%) and age 21-30 years reach (26\%) and underage age groups of 20 years reach $(2 \%)$. 
Figure 1 shows that the productive and capable group. Gender-based violence is based on education level of respondents to work and overcome household obstacles to meet family needs the respondents above 40 years old are categorized as productive age. This gives an illustration that domestic violence is a concern at prime age or young age. Gender based violence in education plays an important role to find job. The average level of high school education is $27 \%$, and junior high school education is $25 \%$, university is $5 \%$. The education level has an effect to improve the quality of human resources. The higher education level the way of thinking will be better. The relatively low percentage of respondents, namely the level of primary school education, had the highest percentage of $31 \%$, as shown in figure 2 .

Figure 2 shows the low education level of poor women effects on quality of human resources and low income level of IDR 900,000 per month is below the poverty line of. The low level decreases the employment competition. Education is a national development goal and women receive lower education than man in every developing country. Education at elementary and secondary school for 108 countries in world shows the women are smaller, at least $10 \%$, compared to number of boys. The largest educational gender gap is found in poorest countries, Middle East and North Africa. The gap between men and women in education with literacy skills for average year school is 29 percent lower than men [29]. Various studies have shown that maternal education plays a role in determining nutritional needs in rural areas. The prevalence of stunted girls (dwarf) becomes indicator of malnutrition. Mother with higher education tends to improve the daughter health than boys as reported by Duncan Thomas [31].

\section{B. Marriage Status of Respondents}

Tsunami, earthquake and liquefaction make the refugees camps condition have worsened due to economic burden of family. Figure 3 showed that that (77\%) these women are widowed and (23\%) are married. These women divorce because their husband do physical and sexual violence and economic violence and unable to meet family needs. The large number of children become burden on family economy and affect on the problem of psychological burden.

\section{Portrait of Life quality of Women in Aftermath of Tsunami and Earthquake}

The study results show that $76 \%$ of widow's conflict prioritizes culture and religion that greatly affect the construction of people's lives. . Women become symbols of guardians of 
norms and moral values. The female violence after the tsunami and earthquake including physical, psychological / emotional, rape and sexual, economic and violence. These have a great influence on women's reproductive health disorders. Figure 4 shows that high frequency was found in psychology and emotions violence (16\%), and economic violence in second ranks $(8 \%)$, followed by physical violence $(4 \%)$, maternal mortality $(1 \%)$, sexual and rape violence and unwanted pregnancy (1\%) and maternal deaths $(2 \%)$.

Figure 4 shows the relationship between the post-tsunami, earthquake and liquefaction of tribal population for the couple violence. Natural disaster factor closely relates with social demographic factors (age, education, marital status). It directly relates to women's reproductive health that consists of maternal health and sexual reproductive health [23], [32]. The prevention and solutions for violence with the couple can be done through family economic empowerment and providing religious enlightenment [28], [33], [34]. The socioeconomic and cultural influences on behavior since maternal pregnancy influences domestic violence. The factors include husband's support, social environmental support, wife's status in family, and financial support in family, gender discrimination against women, reproductive health decision-making authority, and maternal values for family from psychological, economic and social aspects and urgent family need. These will affect the babies born for future generation of nation's children to improve the life quality of human resources and sustainable development based on principle of "Sustainable Development Goals" to improve the life quality of women and elimination of domestic violence [1], [3], [14].

The couple violence was done by husband because he feels frustrated [12], [16], [35]. The husband does not have a permanent job, limited freedom because follow father in-law. This condition will affect the reproductive health of pregnant women who get disorders during pregnancy (75 percent), because the husband is not ready to marry, and women deaths when pregnant (6.7) percent. The husband does not have a permanent job because the economic conditions are still the burden and taking care of children is a high cost of living. Figure 5 show the effect of social conflict on women's violence in household

Figure 5 and Figure 6 shows that the effect of a husband's violence on a wife or vice versa can create deep negative impression. It will lead to ongoing hatred and resentment towards perpetrators, see her husband's violent treatment, and children become afraid and hate to cause trauma to their father. 


\section{DISCUSSION}

Social life portrait of domestic violence after tsunami and earthquake disasters produce women inability to serve the husbands needs to have an effect on an unwanted pregnancy [25]. The poor social life after the disaster and tsunami produced sexual violence in form of forced sexual relations in refugee camps and menstruating wife would have a negative effect on women's reproductive health that showed victims of infectious diseases and mental health disorders [8]. The domestic violence consists of stress, post-trauma, depression, anxiety, low self-esteem, and eating disorders. Informants feel ashamed of her husband's words due to harsh words. Pregnant wives over 40 years old have. They have low education and 3 children or more, live in tents and far from health services. The reproductive age influences the violence of women after tsunami disaster mitigation. The process of pregnancy is initially helped by traditional trained healers, given that doctors and midwives are very far from health care centers. Figure 6 shows the portrait of poor women's social lives affected by gender-based sexuality. The high numbers of violence are economic and physical violence, causing disruption to their reproductive health.

\section{A Portrait of Women Health Quality for Sexual Violence in Post-Tsunami, Earthquake and Liquefaction Disasters}

Most refugee camps are women, elderly and children Violence in a gender perspective at refugee camps were occurred to women, boys and girls after the disasters that hit the cities of Palu, Sigi and Donggala. Sexual harassment was occurred in 90 cases to women and children in refugee camps. The sexual harassment or violence are unavoidable in refugees camp because not conducive situation and there is no privacy space. This violence is solved in collaboration with Local Community institutions to protect the health rights of women and children. Women's tents are not only functioned as a place for empowerment, but also as a place to receive complaints from victims of violence to facilitate reporting and quick handling [8], [11], [26], [36], [37]. 
Population and clinical studies record the relationship between the couple violence and drug abuse problems. The survey results found that treatment of drugs abuse can reduce the risk of the couple violence [28], [34], [37]-[39], in contrast to other studies [18], [35]. The natural disasters of tsunami, earthquakes and liquefaction produce the couple violence to influences women's reproductive health [23], [32]. Women become sick and treatment is done traditionally with herbal medicine or non-medical with help of healer (shamans, supernatural, mystical). They have a belief that sick people are caused by devil. They ask for help from traditional healer to cure the sick. The women gave birth by themselves and only assisted by a traditional healer, then the baby was bathed to give the body's immunity from illnesses and sharp weapons. Many of women consume bananas and peanuts to maintain physical health. A small number of residents sell beans and bananas around the village and cities. Habib Shaleh often provides traditional treatment to community members using herbs. He cure intestinal worms with Moringa leaf, papaya leaf for hypertension, diabetes and other diseases, stomach uses ingredients of sambirata leaves, butrowali. Physical health is cured by eating a little salt, before and after eating. It is believed to prevent poison and 70 types of diseases. Psychological illnesses are treated by prayer water for healing and physical and spiritual safety. The traditional and religious treatment are still done because cheaper and nearer than hospital.

\section{Economic Empowerment for the Family Victims of Domestic Violence}

Empowerment for household violence victim of woment residents produces health physical condition [28]. They do a lot of physical activities to meet life need, such as walking, climbing trees, hoeing land and hunting animals. The solutions to prevent violence use a model of women's empowerment. It is divided into two parts, namely changes in attitudes and changes in skills. The attitude changes include more confident and open to report violence to police, while the skills change include to increase knowledge by increasing women's awareness (22.2 percent), raising public awareness (17.78 percent), increasing family economic empowerment (40 percent) and special legal reform (40 percent). Factors to support the implementation of empowerment include: a) good coordination and cooperation between social services and human resource, b) active and enthusiastic participants to participate in every activity to empower women violence victims, c) good consultation services such as social 
workers, psychologists and volunteers. The respondents live at home around the hills or foggy mountain peaks. The house is not permanent with a length of 4 meters and a width of 2 meters, without a partition or room to do all daily activities. The kitchen (furnace) is placed at back corner of building for cooking and warmer at night. The houses are made from tarpaulin material and bamboo and wood for floors and walls. Woman follow family economic empowerment to make cakes, woven from palm leaves, banana chips, sweet potatoes, pumpkin chips and a kind of tuber plants, bamboo handicrafts, meatballs and various types of food. It can support the livelihoods of Da'a Kaili tribe as farmers and sell chili, bananas and soup leaves and vegetables at market in Palu, Central Sulawesi.

\section{CONCLUSION}

Various domestic violence effect on women physical and psychology health. It produces pregnancy disorders $(59.3 \%)$, infant mortality at birth by $(7 \%)$ and other disorders (40\%). The household violence consists of physical violence (62\%) and economic violence (40\%). The solution to prevent violence is to change the attitudes and skills through family economy empowerment, increasing the women awareness to maintain their reproductive health and violence handling by giving a threat of criminal penalties for perpetrators in accordance with Indonesian law. This research should inspire the policy makers by paying attention to every level of society, community, family and individuals. The community level needs to be reviewed, marriage law should give a standard age of marriage age above 22 years, and review of criminal and civil law, and delaying the of early marriage to prevent husband violence against wives at family level and an inability to serve husband's needs as a cause of violence on women's reproductive health. The family violence should be eliminated through socioeconomic family empowerment and improving the life quality of women and children after the tsunami and earthquake in Central Sulawesi.

\section{Suggestion}

Provincial Government of Central Sulawesi should make policies immediately related to women violence handling. Coordination with Office of Women and Children Empowerment should be done immediately forms a partnership forum to eradicate domestic violence. The government should make protection policies for the women health and children and criminal law for perpetrators of domestic violence.

\section{Acknowledgment}


We would like to thank to Research Directorate and Community Service, Directorate General of Research and Development Strengthening of Research Ministry, Technology and Higher Education of Republic of Indonesia in accordance with 2019 Research Contract Decree Number: 216 / SP2H / LT / DRPM / 2019 dated 11 ${ }^{\text {th }}$ March 2019 to provide research funding assistance to complete this research.

\section{Abbreviations}

Not applicable

\section{Reference}

[1] United Nations, Millennium Development Goals and Beyond 2015. Retrieved from United Nations: https://www.un.org/millenniumgoals/.

[2] K. Carbone-Lopez, F.-A. Esbensen, and B. T. Brick, "Correlates and Consequences of Peer Victimization: Gender Differences in Direct and Indirect Forms of Bullying," Youth Violence and Juvenile Justice, vol. 8, no. 4, pp. 332-350, Oct. 2010, doi: $10.1177 / 1541204010362954$.

[3] World Health Organization, Responding to intimate partner violence and sexual violence against women: WHO clinical and policy guidelines. World Health Organization, 2013.

[4] R. P. Butters, B. A. Droubay, J. L. Seawright, D. R. Tollefson, B. Lundahl, and L. Whitaker, "Intimate Partner Violence Perpetrator Treatment: Tailoring Interventions to Individual Needs," Clin Soc Work J, May 2020, doi: 10.1007/s10615-020-00763-y.

[5] P. Cw, B. S, N. J, and undefined, "Physically and sexually violent experiences of reproductive-aged women displaced by Hurricane Katrina.," J La State Med Soc, vol. 162, no. 5, pp. 282, 284-8, 290, Sep. 2010. https://pubmed.ncbi.nlm.nih.gov/21141260/

[6] E. G. Krug et al., "Suicide after Natural Disasters," New England Journal of Medicine, vol. 338, no. 6, pp. 373-378, Feb. 1998, doi: 10.1056/NEJM199802053380607.

[7] E. Pittaway, L. Bartolomei, and S. Rees, "Neglected Issues and Voices," Asia Pac J Public Health, vol. 19, no. 1_suppl, pp. 69-69, Mar. 2007, doi: 10.1177/101053950701901S11.

[8] S. Fisher, "Violence Against Women and Natural Disasters: Findings From Post-Tsunami Sri Lanka," Violence Against Women, vol. 16, no. 8, pp. 902-918, Aug. 2010, doi: 10.1177/1077801210377649.

[9] M. L. Kelley, S. Self-Brown, B. Le, J. V. Bosson, B. C. Hernandez, and A. T. Gordon, "Predicting posttraumatic stress symptoms in children following Hurricane Katrina: A prospective analysis of the effect of parental distress and parenting practices," Journal of Traumatic Stress, vol. 23, no. 5, pp. 582-590, 2010, doi: 10.1002/jts.20573.

[10] A. Biswas, A. Rahman, S. Mashreky, F. Rahman, and K. Dalal, "Unintentional injuries and parental violence against children during flood: a study in rural Bangladesh," vol. 10, no. 1, 2010, doi: doi 10.22605/RRH1199.

[11] T. Curtis, B. C. Miller, and E. H. Berry, "Changes in reports and incidence of child abuse following natural disasters," Child Abuse \& Neglect, vol. 24, no. 9, pp. 1151-1162, Sep. 2000, doi: 10.1016/S0145-2134(00)00176-9. 
[12] H. T. Keenan, S. W. Marshall, M. A. Nocera, and D. K. Runyan, "Increased incidence of inflicted traumatic brain injury in children after a natural disaster," American Journal of Preventive Medicine, vol. 26, no. 3, pp. 189-193, Apr. 2004, doi: 10.1016/j.amepre.2003.10.023.

[13] H. U. Chih-Pei and Y.-Y. CHANG, "John W. Creswell, research design: Qualitative, quantitative, and mixed methods approaches," Journal of Social and Administrative $\begin{array}{llllll}\text { Sciences, } & \text { vol. } \quad 4, \quad \text { no. } & 2, & \text { pp. } & 205-207, & \end{array}$ http://kspjournals.org/index.php/JSAS/article/view/1313

[14] World Health Organization, "Interpersonal Violence \& Disasters," Departmen of Injuries and Violence Prevention, Geneva, 2005. [Online]. Available: https://www.who.int/violence_injury_prevention/publications/violence/violence_disasters. pdf?ua $=1$.

[15] A. K. Goenjian et al., "Posttraumatic Stress and Depressive Reactions Among Nicaraguan Adolescents After Hurricane Mitch,” AJP, vol. 158, no. 5, pp. 788-794, May 2001, doi: 10.1176/appi.ajp.158.5.788.

[16] T.-H. Lu, "Earthquake and suicide: bringing context back into disaster epidemiological studies," Int J Epidemiol, vol. 33, no. 6, pp. 1406-1409, Dec. 2004, doi: 10.1093/ije/dyh234.

[17] H.-C. Wu et al., "Survey of Quality of Life and Related Risk Factors for a Taiwanese Village Population 3 Years Post-Earthquake," Aust N Z J Psychiatry, vol. 40, no. 4, pp. 355-361, Apr. 2006, doi: 10.1080/j.1440-1614.2006.01802.x.

[18] Badan Nasional Penaggulangan Bencana, "Data Kematian dan Jumlah Penduduk Korban Tsunami, Gempa Bumi dan Likuifaksi Sulawesi Tengah," 2018. http://litbang.pu.go.id/puskim/source/pdf/Laporan\%20Kajian\%20Gempa\%20Palu\%20Sula wesi\%20Tengah.pdf

[19] United Nations, "Sustainable Development Goals (SDGs), 2019 "Helping Government and Stakeholders Make the SDG's a Reality Gender Equality," New York, 2019. [Online]. Available: https://unstats.un.org/sdgs/report/2019/The-Sustainable-Development-GoalsReport-2019.pdf.

[20] J. True, "Gendered violence in natural disasters: Learning from New Orleans, Haiti and Christchurch," Aotearoa New Zealand Social Work, vol. 25, no. 2, Art. no. 2, 2013, doi: 10.11157/anzswj-vol25iss2id83.

[21] A. P. DePrince, N. Wright, K. L. Gagnon, T. Srinivas, and J. Labus, "Social Reactions and Women's Decisions to Report Sexual Assault to Law Enforcement," Violence Against Women, vol. 26, no. 5, pp. 399-416, Apr. 2020, doi: 10.1177/1077801219838345.

[22] M. Anastario, N. Shehab, and L. Lawry, "Increased gender-based violence among women internally displaced in Mississippi 2 years post-Hurricane Katrina," Disaster Medicine and Public Health Preparedness, vol. 3, no. 1, pp. 18-26, 2009, doi: 10.1097/DMP.0b013e3181979c32.

[23] A. J. Taft, R. L. Powell, and L. F. Watson, "The impact of violence against women on reproductive health and child mortality in Timor-Leste," Australian and New Zealand Journal of Public Health, vol. 39, no. 2, pp. 177-181, 2015, doi: 10.1111/17536405.12339.

[24] E. Leen, E. Sorbring, M. Mawer, E. Holdsworth, B. Helsing, and E. Bowen, "Prevalence, dynamic risk factors and the efficacy of primary interventions for adolescent 
dating violence: An international review," Aggression and Violent Behavior, vol. 18, no. 1, pp. 159-174, Jan. 2013, doi: 10.1016/j.avb.2012.11.015.

[25] L. A. Barufaldi et al., "Gender violence: a comparison of mortality from aggression against women who have and have not previously reported violence," Ciênc. saúde coletiva, vol. 22, pp. 2929-2938, Sep. 2017, doi: 10.1590/1413-81232017229.12712017.

[26] M. Black et al., "National Intimate Partner and Sexual Violence Survey: 2010 Summary Report," 2011, Accessed: Aug. 25, 2020. [Online]. Available: https://ncvc.dspacedirect.org/handle/20.500.11990/250.

[27] A. L. Coker et al., "Evaluation of the Green Dot Bystander Intervention to Reduce Interpersonal Violence Among College Students Across Three Campuses," Violence Against Women, vol. 21, no. 12, pp. 1507-1527, Dec. 2015, doi: $10.1177 / 1077801214545284$.

[28] M. Masin-Moyer, "A Comparative Effectiveness Study of the Trauma Recovery Empowerment Model (TREM) and an Attachment-Informed Variation of TREM," $\begin{array}{llll}\text { University of Pennsylvania, } & \text { USA, }\end{array}$ https://sswr.confex.com/sswr/2018/webprogram/Paper30630.html

[29] S. M. Stith, E. E. McCollum, Y. Amanor-Boadu, and D. Smith, "Systemic Perspectives on Intimate Partner Violence Treatment," Journal of Marital and Family Therapy, vol. 38, no. 1, pp. 220-240, 2012, doi: 10.1111/j.1752-0606.2011.00245.x.

[30] M. O’Neil and P. Morgan, “American perceptions of sexual violence," Washington, DC: FrameWorks Institute, 2010.

[31] M. P. Todaro and S. C. Smith, Pembangunan Ekonomi Jilid 1. Jakarta: Erlangga, 2006.

[32] A. Taft and L. Watson, "Violence against women in Timor-Leste: Secondary analysis of the 2009-10 demographic health survey-final report.," 2013. https://www.latrobe.edu.au/_data/assets/pdf_file/0019/540208/Taft_Watson_East-Timorreport-2013.pdf

[33] M. M. Cavanaugh, "Theories of Violence: Social Science Perspectives," Journal of Human Behavior in the Social Environment, vol. 22, no. 5, pp. 607-618, Jun. 2012, doi: 10.1080/10911359.2011.598757.

[34] C. M. Murphy and L. Ting, "The effects of treatment for substance use problems on intimate partner violence: A review of empirical data," Aggression and Violent Behavior, vol. 15, no. 5, pp. 325-333, Sep. 2010, doi: 10.1016/j.avb.2010.01.006.

[35] S. Lloyd, "The Effects of Domestic Violence on Women's Employment," Law \& Policy, vol. 19, no. 2, pp. 139-167, 1997, doi: 10.1111/1467-9930.00025.

[36] J. A. Cohen, L. H. Jaycox, D. W. Walker, A. P. Mannarino, A. K. Langley, and J. L. DuClos, "Treating Traumatized Children after Hurricane Katrina: Project Fleur-de Lis" Clin Child Fam Psychol Rev, vol. 12, no. 1, pp. 55-64, Mar. 2009, doi: 10.1007/s10567009-0039-2.

[37] M. Rezaeian, “The association between natural disasters and violence: A systematic review of the literature and a call for more epidemiological studies," J Res Med Sci, vol. 18, no. 12, pp. 1103-1107, 2013. https://www.ncbi.nlm.nih.gov/pmc/articles/PMC3908534/

[38] M. Rezaeian, "War is an unjustifiable man-made disaster within the Eastern Mediterranean Region," WORLD FAMILY MEDICINE, vol. 6, no. 6, pp. 14-16, 2008. https://www.researchgate.net/publication/268279042_War_is_an_unjustifiable_manmade_disaster_within_the_Eastern_Mediterranean_Region 
[39] M. Rezaeian, "A review on the most important consequences of wars and armed conflicts," Middle East J Business, vol. 4, no. 1, pp. 7-9, 2009.

\section{Figures}

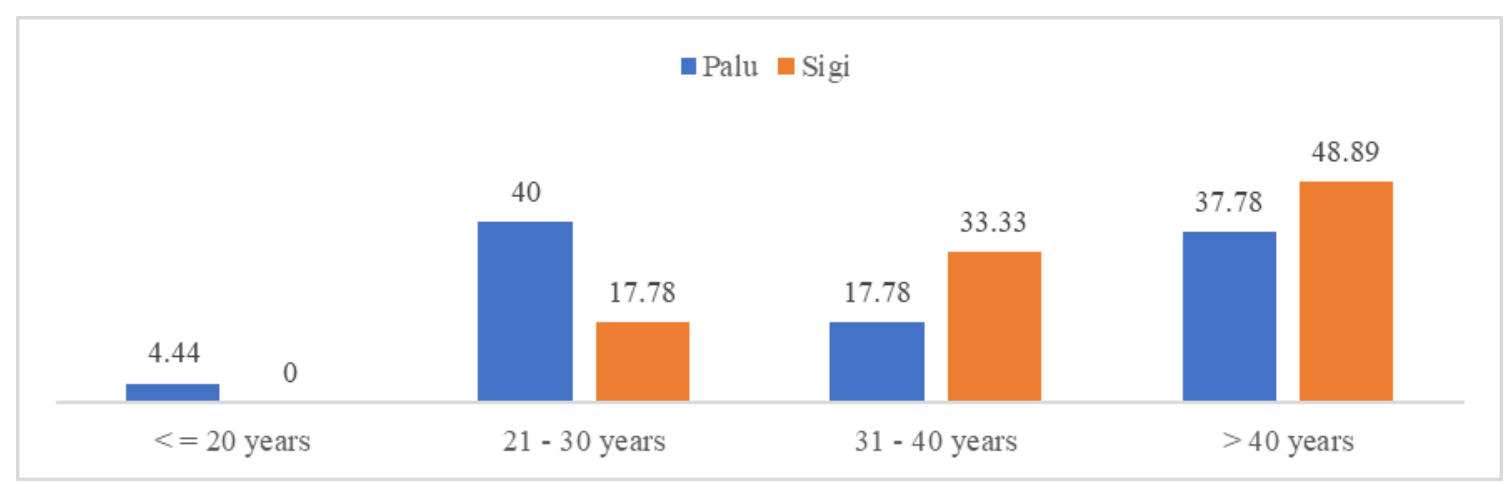

Figure 1. Age Group of Respondents

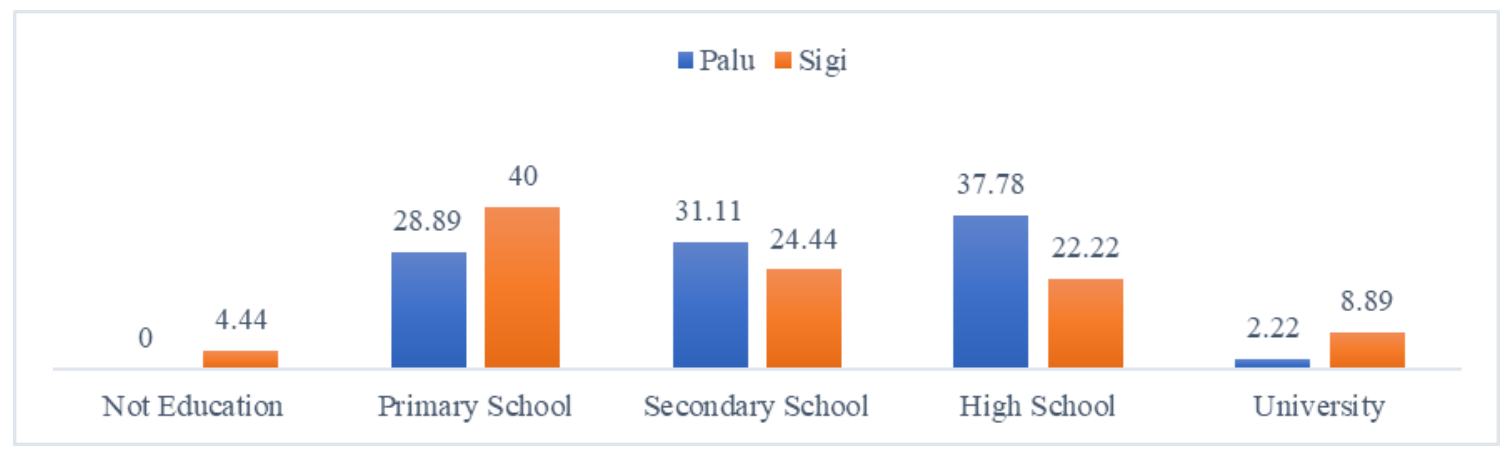

Figure 2. Education level of Respondents

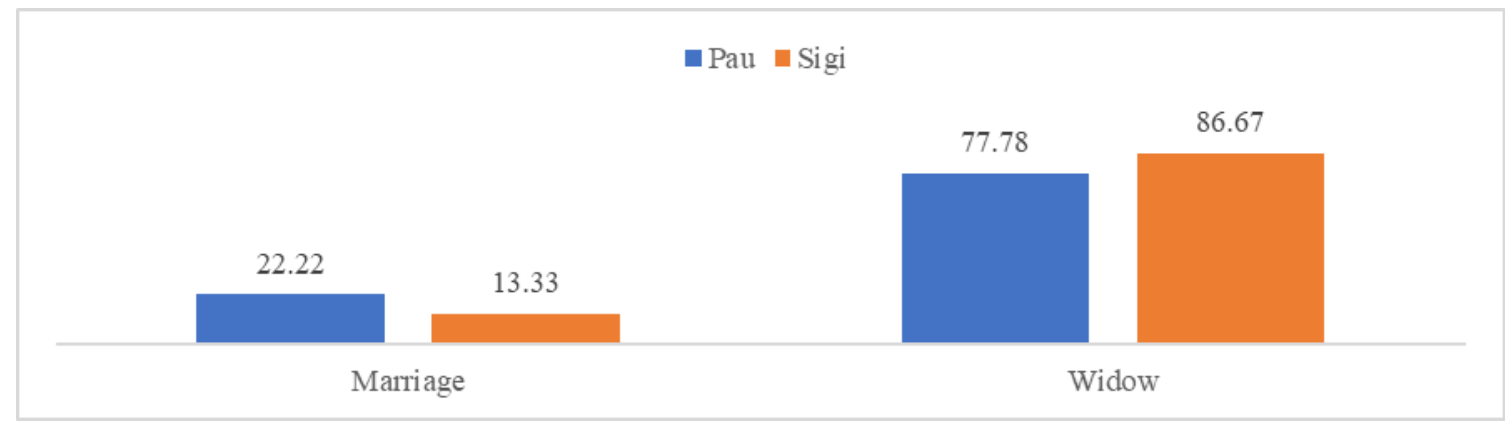

Figure 3. Marriage Status 


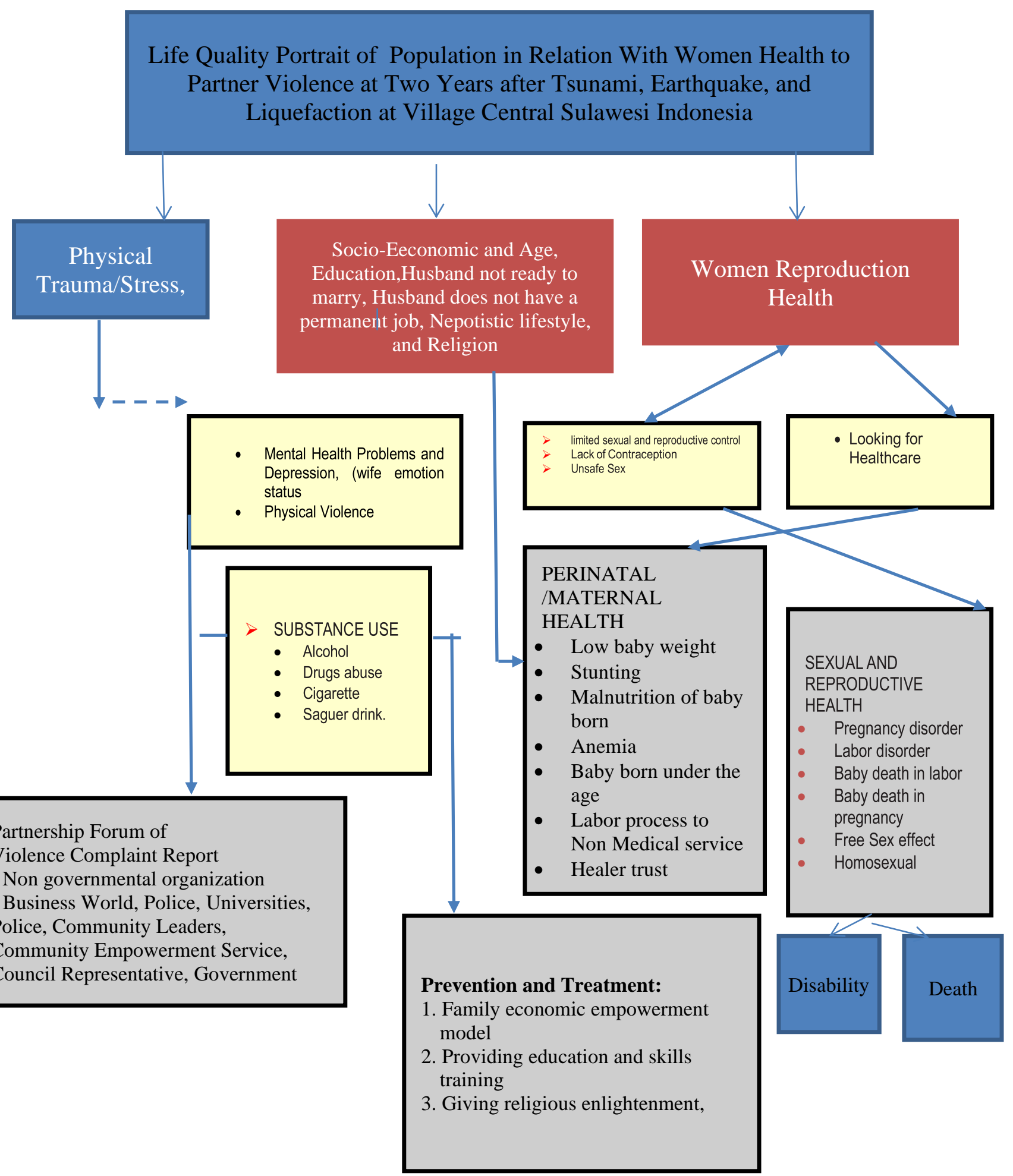

Figure 4. Relationship between Post-Natural Disasters and Violence 


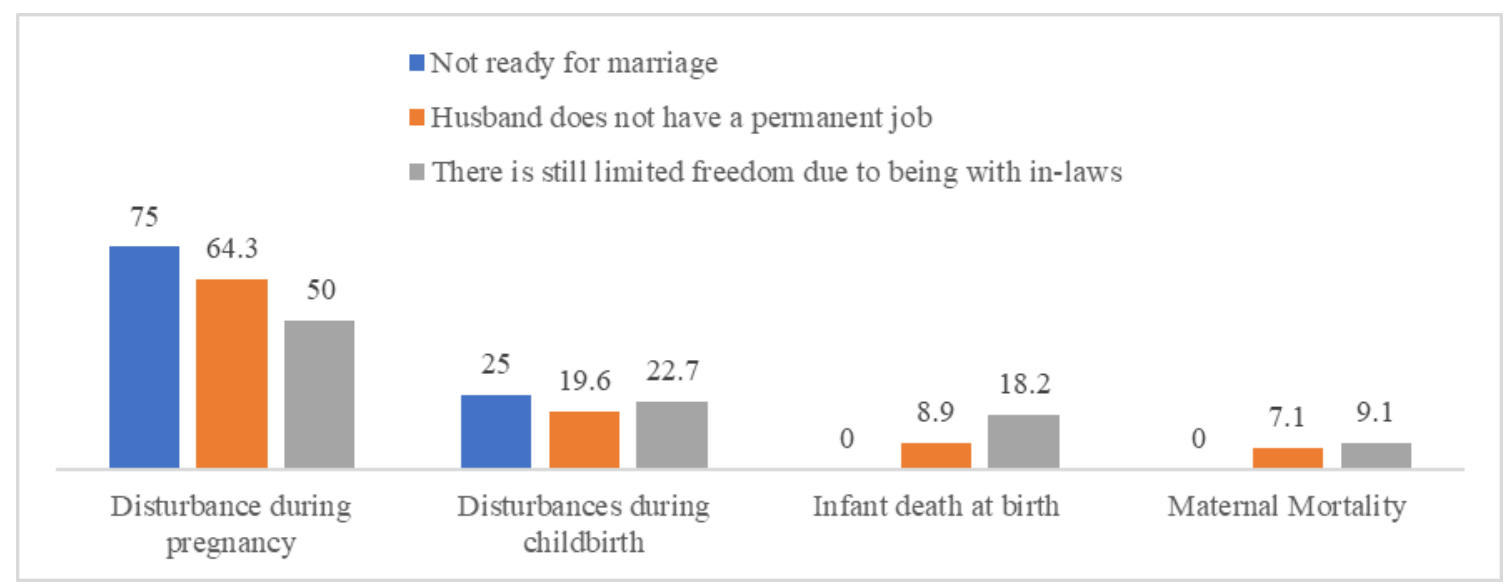

Figure 5 Effect of household violence on women reproductive health

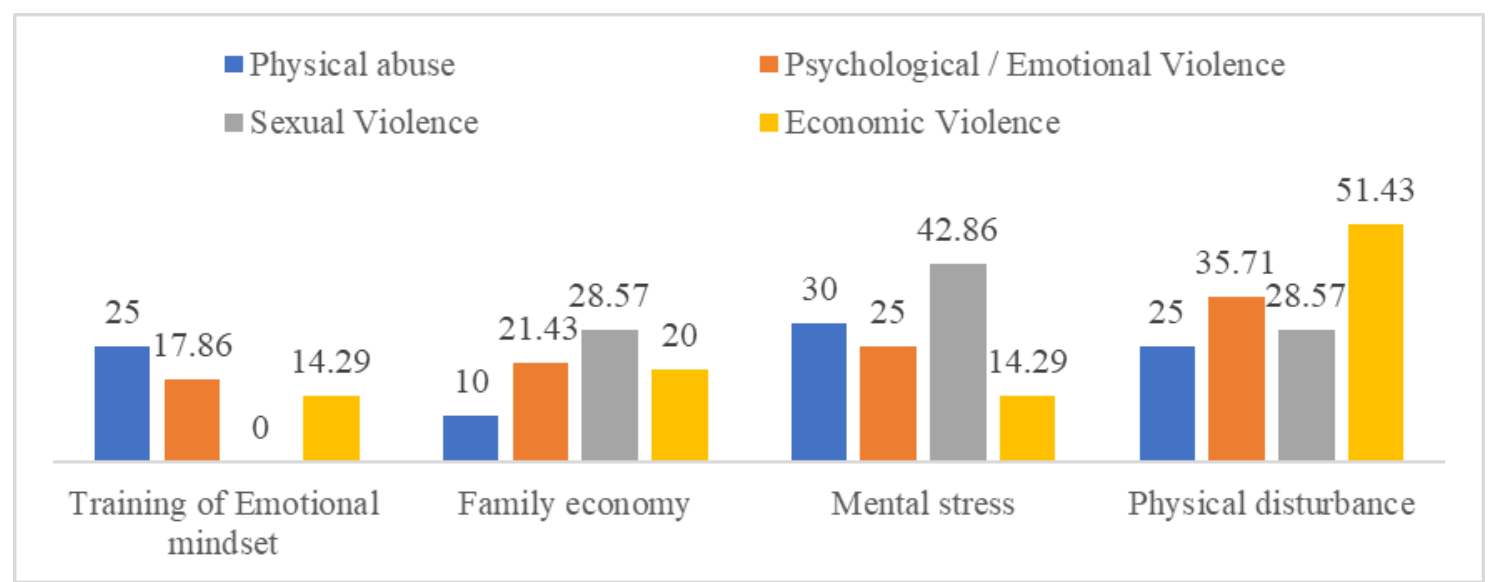

Figure 6 The Effect of The Couple Violence on Women's Reproductive Health 